\title{
Hospital admission flow and nutritional support in a cohort of pediatric patients with COVID-19
}

\section{Aline Pereira Queiroz 1}

iD https://orcid.org/0000-0002-9325-408X

Caroline dos Santos 2

(iD) https://orcid.org/0000-0001-8050-015X

Greice Milena Sant'Ana Reis 3

D.tps://orcid.org/0000-0002-7880-5402

Paulo Sergio Carvalho Matos 4

https://orcid.org/0000-0003-0747-4789

\author{
Rogério dos Santos e Santos 5 \\ iD https://orcid.org/0000-0002-1923-4611 \\ Tamires de Jesus Silva 6 \\ iD https://orcid.org/0000-0002-0482-4600
}

1 Programa de Pós-graduação em Processos Interativos de Órgãos e Sistema. Universidade Federal da Bahia. Avenida Reitor Miguel Calmon s.n. Vale do Canela, $4^{\circ}$ andar,
Sala 404. Salvador, Bahia, Brasil. CEP: 40.110-902. E-mail: alinepereiranutricao@gmail.com

2-7 Setor de Nutrição Assistencial. Hospital Martagão Gesteira. Salvador, BA, Brasil.

\begin{abstract}
In view of the current panorama of hospital nutritional care, it is necessary to review nutritional care practices in hospital units, in order to ensure nutritional monitoring and quality of care. Therefore, it is necessary to build flows of nutritional assistance practices at the pediatric hospital level, based on the recommendations of the Federal Council of Nutritionists and the Brazilian Society of Parenteral and Enteral Nutrition, aiming at not generating a deficit in the nutritional monitoring of the patient and in reducing the risk of contamination of the professional. When individual protection equipment is available, nutritional admission will be made in person and during hospitalization, monitoring can be performed using secondary data from electronic medical records and / or telecommunication with the multidisciplinary team. The implementation of nutritional routines in hospitals in times of Covid-19 pandemic generates more assertive conducts for the prevention and treatment of malnutrition and other nutritional implications, also guaranteeing the safety of professionals in assistance in pediatric units..
\end{abstract}

Key words Nutritional therapy, Diet therapy, COVID-19, Pediatrics, Workflow

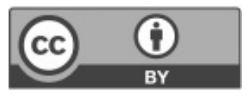




\section{Introduction}

Since its first identification in Wuhan, China, in December 2019, the new Coronavirus (SARS-COV2) has been infecting thousands of people, of different ages, causing several deaths. ${ }^{1}$ Thereare few bibliographic data concerning the effects of this pandemic specifically to the pediatric population Until now, the most effective method to minimize the mortality rate and the need for intensive care is attempting to shelter vulnerable groups and to delay the propagation of the virus. ${ }^{2}$

Before the current prospect of hospital clinical care, it is necessary to review the practices of nutritional assistance in hospital units, aiming to assure nutritional management and quality of care, without interfering in the safety of both patients and professionals, and even mitigating the risk of virus propagation. ${ }^{3}$

Considering the recommendations of social distancing, some attributions of nutritionists in the hospital environment have been questioned, in an attempt to minimize the exposition of the professionals to people with COVID-19. In this way, the Federal Council of Nutritionists (CFN - Portuguese acronym) and the Brazilian Society of Enteral and Parenteral Nutrition (BRASPEN - Portuguese acronym), in their feedback about coping with COVID-19 in hospitalized patients, recommend to avoid physical contact of the nutritionists with the patients, mainly in suspect or confirmed cases of coronavirus. 4,5

In the process of nutritional admission, the nutritionist has as practices the execution of anamnesis, anthropometric assessment and applying of a nutritional risk screening. These practices must be executed within 48 hours after hospitalization. Furthermore, it is routine for the nutrition professional to execute semiological examination, visits to the patient's bed according to the nutritional risk level and registry of the patients' evolution in a medical record. 6

However, during the new coronavirus pandemic, modifications were suggested in the hospital routine of the nutritionists, in an attempt of avoiding dissemination of the disease. The nutritional follow-up may be executed by means of data collection in electronic medical records or telecommunication. In exceptional cases, when a presential visit is necessary, it is imperative the usage of personal protective equipment (EPP) recommended by the Service of Hospital Infection Control of the Unit (SCIH Portuguese acronym), contributing to ensure an effective and safe nutritional care.
Hence, the objective is to share routines and conducts for the nutritionists, in a Covid-19 cohort in a pediatric hospital, aiming to assure the maintenance of adequate nutritional care and mitigation of the risk of infection.

\section{Methods}

Descriptive research executed for the building of the flow of nutritional care practices in pediatric hospital level, based on recommendations of CFN and BRASPEN in face of the current pandemic prospect in Brazil.3,4 Documents from these regulatory authorities were used as base material for the elaboration of the admission and nutritional support flow of the patients hospitalized in the cohort units for COVID-19.

The locus of the study was the Philanthropic Pediatric Hospital located in the city of Salvador/BA, which has a clinical nursery with 40 beds and an ICU with 10 beds, where patients with COVID-19 are followed, as well as suspect cases. The determination of cohort units, associated with the change in the admission flow and nutritional management started in April 2020 keeping up to the current moment. The isolation in cohorts consists in delimiting a specific area in the same nursery or clinical sectors in their totality to assist exclusively patients infected by or in suspicion of having the new coronavirus.

\section{Nutritional Admission of Pediatric Patients with COVID-19}

The evaluation of nutritional risk screening of the patients admitted in hospital units is mandatory and recommended within $48 \mathrm{~h}$ of admission. In order to screen the nutritional risk of children and adolescent the STRONG Kids (Screening Tool Riskon Nutritional Status and Growth) tool is used, translated and validated to the Brazilian population. ${ }^{7}$ This scale considers the current nutritional status, involuntary loss of weight (for children $>1$ year) or absence/insufficiency of weight gain (for children $>1$ year), gastrointestinal alterations and of food intake, besides comorbidities. 7 These data can be collected by electronic medical records, in the case of they are available.

Considering the possible clinical complications concerning the new coronavirus, the nutritional risk may indicate better or worse prognostic. Thus, we consider that nutritional screening for pediatric patients with COVID-19 must be adapted, including, besides the nutritional risk criteria for pediatric 
population (cystic fibrosis, oncologic disease, prematurity, Malabsorption syndromes, major surgeries, anthropometric indicators $<\mathrm{z}-3$ ou $\geq \mathrm{z}-3$ e $<\mathrm{z}-2$, high risk or pressure injury, immunosuppressed, severe arterial hypertension, insulin dependent diabetes, kidney insufficiency), comorbidities described in the flow of nutritional assistance to patients with COVID-19 or SCOVID-19 from BRASPEN5: unappetizing, persistent diarrhea, asthma and structural pneumopathies.

Pediatric patients hospitalized in the unit with suspicion or confirmation of coronavirus infection will be admitted presentially by the nutritionist, since there is availability of all necessary EPP for the professional's safety. The SCIH of the studied hospital recommends as essential EPP for presential attending: N95 or FFP2 masks, disposable apron, ocular protection (glasses or face shield), disposable gloves and full safety shoes.

In this initial moment, the nutritionist executes nutritional anamnesis, collects anthropometric measurements of height and weight declared by the companion and applies nutritional risk screening. In case of unfamiliarity of the measurements and unavailability of EPP, estimated height measurement and brachial circumference evaluation can be executed for the management of the nutritional status according to techniques described in Nutritional Screening for Children and Adolescent Manual. ${ }^{8}$

The screening of the nutritional status can be identified and monitored, besides the anthropometry, by laboratory markers such as: nitrogen balance, albumin and transferrin. ${ }^{8}$ These, in turn, must have their results detailed in the electronic medical record. Thus, it is important to highlight that EPP are priorities for the medical assistance teams, as well as nursery and physiotherapy teams, in this way, in case of low stock the nutrition team should maintain the monitoring through the electronic record used in medical and nursery evolutions and results of biochemical tests.

Besides that, information on physical exam must be collected from electronic records. In the course of hospitalization, the nutritionist will not have any other encounter with the patient, except for exceptional cases, where her/his presence is needed, without possibility of resolution by telecommunication.

\section{Diet Therapy and Nutritional Therapy}

The nutritional offer must be primarily oral, with a consistence compatible with the acceptance in nonsevere patients with COVID-19 diagnosis. The determination of the energy/protein needs must consider patient's age, nutritional status and clinical conditions. 5,7

Patients with 0 to 2 years of breastfeeding can continue with the practice even with mothers bearing COVID-19, in case of a stable clinical condition. ${ }^{9}$ However, some authors suggest that in situations of more severe maternal condition, the temporary separation of the newborn may be necessary, aiming to minimize the risk of infection of the neonate by respiratory secretions from the mother. In these cases, mothers can withdraw their milk, which can be offered to the newborn by designated caregivers, paying attention on the adequate sanitation of the pumps and their components each time the milk is drained. 10

Generally, to establish or reestablish the mother/baby contact, it is recommended to follow strictly the hand hygiene orientations before handling him/her and to use facemask during the breastfeeding, or in case of not feeling safe to breastfeed, the process of manual extraction of breast milk, milking or pumping can be used following the correct processes of hand and breast hygiene, as well as the tools used for milking. 9

These practices will favor the lactating baby to have all the nutritional benefits of the breast milk and a lower risk of infection. ${ }^{9}$ The presence of virus in placenta, amniotic fluid, cord blood or breast milk has not been observed, and the cases described in newborns occurred dued to post-natal acquisition, 1012 with no evidence until the current moment, of vertical mother-baby transmission. In this way, breast milk can provide factors of protection to the baby after maternal COVID-1910 and the practice of breastfeeding must be encouraged. 9

\section{Enteral Nutrition Therapy}

The enteral nutrition therapy (ENT) must be set for severe patients during 24-48 hours after admission, in case of hemodynamic compensation. ${ }^{5}$ In this case, telecommunication will be used between the nutritionist and the multidisciplinary team, for conduct alignment and indication of a more appropriate diet. In order to optimize the onset of ENT, the placement of a nasoenteral or oroenteral probe must be introduced in the moment of orotracheal intubation, performing radiography in the same moment to confirm the position of probe and onset of diet. ${ }^{13} \mathrm{In}$ case of contraindication of oral and/or enteral tract, parenteral nutrition should be started as brief as possible. 5

ENT should not be postponed in the following cases: the use of neuromuscular blockers, protective mechanical ventilation and prone positioning for 
patients with severe acute respiratory syndrome (SARS). In this situation, the NEP passage should be prioritized before the execution of the maneuver and enteral diet should be started after stabilization of the patient. For higher tolerance, the position of the post-pyloric tube and the use of prokinetics can be evaluated. Maintaining the hydric balance is considered highly important in cases of SARS, considering the caloric density of formulas and dilution of modules. ${ }^{14}$ The nutritionist, together with the multidisciplinary team, will follow the tolerance to the enteral diet and will indicate necessary adjustments based on information registered in electronic medical records.

The placement of nasogastric tube should be evaluated in patients that need non-invasive ventilation (NIV), for it might result in alteration of its efficacy due to the air leakage and stomach dilatation, which can interfere in the diaphragm function, leading to postponing of the ENT onset, higher time of ICU stay with higher risk of malnutrition and comorbidities.

Enteral diet should be suspended in cases of decompensated hypoxemia, hypercapnia or severe acidosis and/or other organic dysfunctions that lead to the use of high doses of drugs. The ENT is not recommended to patients with hemodynamic instability; hyperlactatemia, metabolic acidosis, severe hypercapnia associated with acidosis, decompensated hypoxemia and severe electrolytic disturbances. 5

Given the above and considering recommendations of nutritional assistance for patients in suspicion or confirmation of COVID-19, we elaborated the admission and assistance flow and nutritional support for patients in pediatric hospital unit (Figure $1)$.

\section{Advantages and limitations in the new flow applicability}

Combating COVID-19 has become a challenge for the entire multidisciplinary assistance team of the frontline hospitals in the treatment of new coronavirus.

The maintenance of an efficient nutrition is indispensable to the integrative care of the hospitalize patient. However, in face of the current challenge, it is perceived as a limitation of this new model the update of anthropometric measurements necessary to compose the clinical nutritional diagnosis, efficient telecommunication in every moments, availability of complete information in electronic medical records and access to EPP.

However, we understand that nutritional assistance was not jeopardized, for with EPP availability, requests that needed visits at bed were adequately assisted. Besides that, with the adaptation and interaction of the team, information concerning each clinical case are made available in electronic records, making feasible the nutritionist performance in the effective elaboration of nutritional strategies that promote adequate nutrition, preventing malnutrition and enhancing patient's prognosis.

Thereby, the new assistance model for nutritionists with reduction of physical contact with infected patients, preventing virus dissemination between team and patients ensures nutritional support and health of the professional.

\section{Author's contribution}

Queiroz AP idealized the article construction with the theme adoption. Participated in data building, writing and adjustments in the article. Santos C participated in data building, writing of the manuscript and abstract. Sant'Ana Reis GM participated in data building, writing and adjustments in the article; Matos PSC participated in the writing of the article and elaboration of the flowchart; Santos and Santos R participated in the writing of the article. Silva TJ participated in the writing of the article and translation of the abstract. All authors approved the final version of the manuscript. 


\section{Figure 1}

Admission and assistance flow of patients admitted with suspicion or confirmation of Covid-19 and Scovid-19 in pediatric hospital unit. Salvador, BA, 2020.

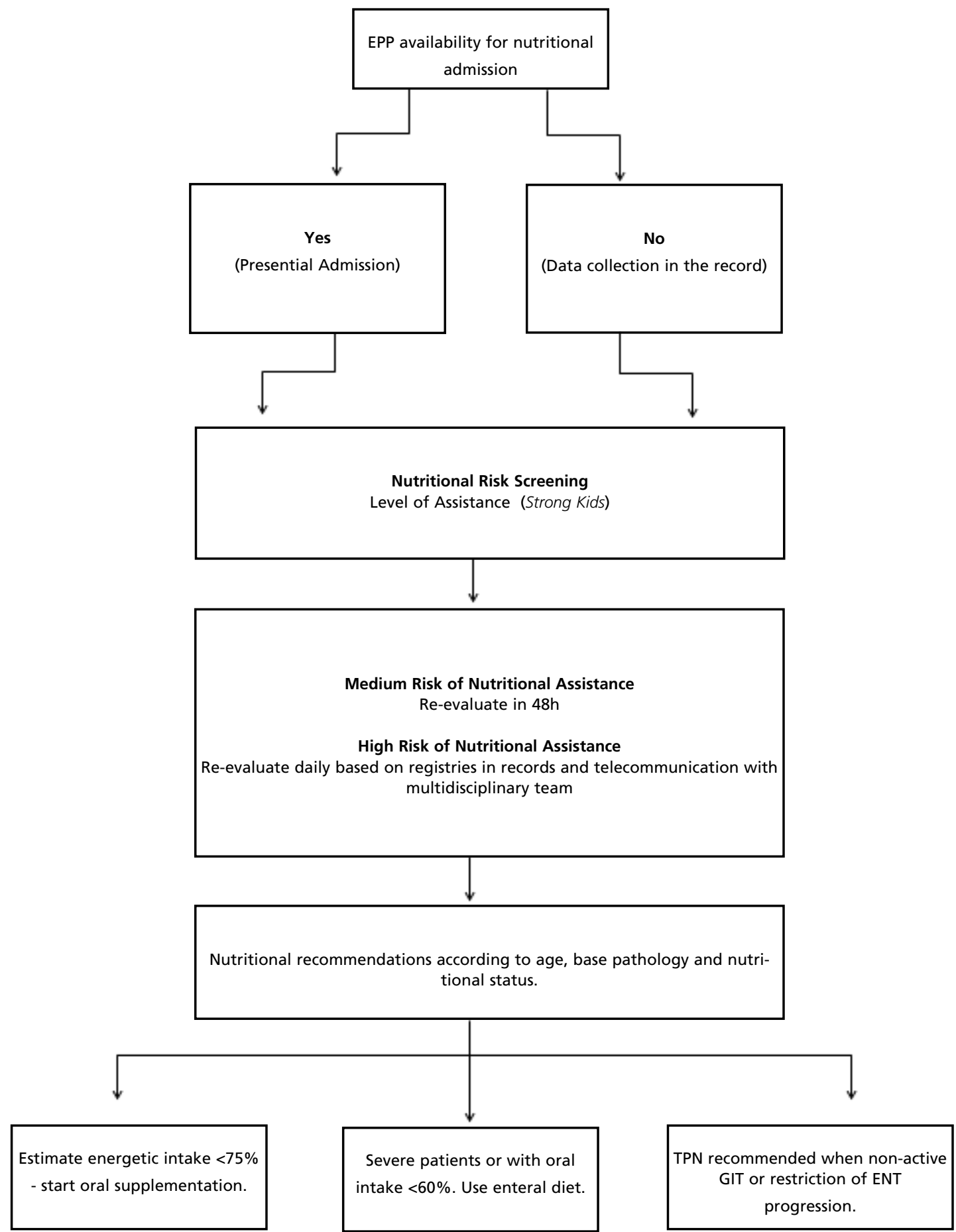

EPP = equipment of personal protection; TPN= Total parenteral nutrition; GIT = Gastrointestinal tract; ENT = Enteral nutritional therapy. 


\section{References}

1. Singhal T. A Review of Coronavirus Disease-2019 (COVID-19). Indian J Pediatr. 2020; 87 (4): 281-6.

2. Brodin P. Why is COVID-19 so mild in children? Acta Paediatr. 2020; 109 (6): 1082-3.

3. Piovacari SMF, Santos GFCG, Santana GA, Scacchetti T, Castro MG. Fluxo de assistência nutricional para pacientes admitidos com COVID-19 e SCOVID-19 em unidade hospitalar. Braspen J. 2020; 35 (1): 6-8.

4. Conselho Federal e Regional de Nutricionistas. Recomendações do CFN: Boas para a atuação do nutricionista e técnico de nutrição e dietética durante a pandemia do novo coronavírus (COVID-19). $3^{\mathrm{a}}$. ed revisada e ampliada. Brasília, DF; 2020 [acesso 6 abr 2020]. Disponível em: https://www.cfn.org.br/wpcontent/uploads/ 2020/03/nota_coronavirus_3-1.pdf

5. Campos LF, Barreto PA, Ceniccola GD, Gonçalves RC, Matos LBN, Zambelli CMSF, Castro MG. Parecer BRASPEN/AMIB para o Enfrentamento do COVID-19 em Pacientes Hospitalizados. Braspen J. 2020; 35 (1): 3-5.

6. Brasil. Conselho Federal de Nutricionistas. Resolução CFN $\mathrm{N}^{\circ} 600$, de 25 de fevereiro de 2018. Dispõe sobre a definição das áreas de atuação do nutricionista e suas atribuições. [acesso 9 abr 2020]. Disponível em: https://www.cfn.org.br/wp-content/uploads/resolucoes/ Res_600_2018.htm

7. Gomes DF, Gandolfo AS, Oliveira AC, Potenza ALS Micelli CLO, Almeida CB, Matsuba CS, Prado CP, Verotti C, Oliveira FLC, Meneses JFS, Almeida LBM, Murra MS, Moretti MYRS, Silva MMDG, Zamberlan P, Feferbaum R, Benzecry SG, Piovacari SMF, Konstantyner T, Figueira VACR, Souza FIS. Campanha "Diga não à desnutrição Kids": 11 passos importantes para combater a desnutrição hospitalar. Braspen J. 2019; 34 (1): 3-23.

8. Sociedade Brasileira de Pediatria. Avaliação Nutricional da Criança e do Adolescente: Manual de orientação. Departamento de Nutrologia. [Online]. Rio de Janeiro, Brasil; 2009. [acesso 9 abr 2020]. Disponível em: https://www.sbp.com.br/fileadmin/user_upload/2015/02/ma nual-aval-nutr2009.pdf

9. Sociedade Brasileira de Pediatria.O Aleitamento Materno em Tempos de Covid-19. Departamento Científico deAleitamento Materno. [Online]. Rio de Janeiro, Brasil; 2020. [acesso 12 mar 2020]. Disponível em: https://www.sbp.com.br/fileadmin/user_upload/22393cNota_de_Alerta_sobe_Aleitam_Materno_nos_Tempos_CO VID-19.pdf

Received on May 12, 2020

Approved on December 9, 2020
10. Puopolo KM, Hudak ML, Kimberlin DW, Cummings J. Management of Infants Born to Mothers with COVID-19. American Academy of Pediatrics Committee on Fetus and Newborn, Section on Neonatal Perinatal Medicine, and Committee on Infectious Diseases. 2020. [acesso 9 abr 2020]. Disponível em: https://www.tn.gov/content/dam/ tn/health/documents/cedep/novel-coronavirus/AAP COVID-19-Initial-Newborn-Guidance.pdf

11. Sociedade Brasileira de Pediatria. A criança com cardiopatia nos tempos de COVID-19: Posicionamento oficial conjunto. Departamento Científico de Cardiologia da Sociedade Brasileira de Pediatria - Departamento de Cardiopatias Congênitas e Cardiologia Pediátrica da Sociedade Brasileira de Cardiologia - Departamento de Cirurgia Cardiovascular Pediátrica da Sociedade Brasileira de Cirurgia Cardiovascular [Online]. Rio de Janeiro, Brasil; 2020. [acesso 4 abr 2020]. Disponível em: https://www.sbp.com.br/fileadmin/user_upload/22421bNota_Alerta_-Crianca_Cardiopatia_nos tempos_COVID19.pdf

12. Brasil. Ministério da Saúde. Fundação Oswaldo Cruz. Rede Brasileira de Banco de Leite Humano. Recomendação Técnica No.01/20.170320. Assunto: Covid e amamentação. [acesso 8 ago 2020]. Disponível em: https://rblh.fiocruz.br/sites/rblh.fiocruz.br/files/usuario/80/r blh_recomendacao_01020_170320.pdf

13. Martindale R, Patel JJ. Nutrition Therapy in the Patient with COVID-19 Disease Requiring ICU Care. 2020; 8.

14. Associação de Medicina Intensiva Brasileira. Sugestões para assistência nutricional de pacientes críticos com SARS-COV-2 pelo Departamento de Nutrição. [Online]. São Paulo, Brasil; 2020. [acesso 4 abr 2020]. Disponível em:https://www.amib.org.br/fileadmin/user_upload/amib/2 020/marco/29/SUGESTOES PARA ASSISTENCIA NUT RICIONAL_DE_PACIENTES_CRITICOS_COM_SARSCOV-

\section{PELO_DEPARTAMENTO_DE_NUTRICAO.pdf}

15. Sociedade Brasileira de Pediatria. Terapia nutricional hospitalar para a COVID-19 em crianças. Departamento científico de suporte nutricional. [Online]. Rio de Janeiro, Brasil; 2020. [acesso $6 \mathrm{dez} 2020]$. Disponível em:https://www.sbp.com.br/fileadmin/user_upload/22545cNA - Terapia nutricional hospitalar_p_a COVID19_em_crc.pdf 